\title{
Effects of Moringa based Feed Additives on the Growth Performance and Carcass Quality of Broiler Chicken
}

\author{
L.S. David ${ }^{*}$, J.K. Vidanarachchi ${ }^{1}$, K. Samarasinghe ${ }^{1}$, H.W. Cyril and ${ }^{1}$ C.M.B. Dematawewa ${ }^{1}$
}

Postgraduate Institute of Agriculture

University of Peradeniya

Peradeniya, Sri Lanka

\begin{abstract}
The effects of selected herbal dietary supplements on the growth performance and carcass quality of broiler chicken were investigated. Three hundred and eight day-old, male broiler chicks of Indian River strain were randomly allotted to seven experimental diets namely negative control, $0.0125 \%$ flavomycin (positive control), $0.1 \%$ Moringa leaf powder (MLP), 0.05\% Moringa leaf powder, 0.035\% Zigbir ® (commercial herbal product), $0.1 \%$ Moringa fruit powder (MFP) and $0.05 \%$ Moringa fruit powder, in a complete randomized design. Each treatment contained 44 birds with four replicates of 11 birds each. The body weights and feed consumption was recorded at weekly intervals. Body weight gains and feed conversion ratio (FCR) were calculated. On $42^{\text {nd }}$ day birds were slaughtered and the weight after bleeding, weight after defeathering, total organ weight and dressed weight of individual birds were measured. The carcass quality parameters such as abdominal (fat around gizzard, vent and heart) and subcutaneous (neck, breast and leg) fat contents of five samples from each replicate were determined. The study revealed that all selected herbal dietary supplements significantly $(P<0.05)$ improved the growth performance and carcass yield of broiler chicken compared to the negative control. Among the herbal feed additives, the commercial herbal product Zigbir $^{\circledR}$ was the most effective in improving the growth performance of broiler chicken. Moringa fruit powder of $0.1 \%$ increased the gizzard fat content while $0.1 \%$ Moringa leaf powder reduced the same. This study revealed that replacing antibiotic growth promoters with herbal supplements has beneficial effects on the growth performance and carcass yield of broiler chicken.
\end{abstract}

Keywords: Broiler chicken, carcass, growth, moringa, zigbir $^{\circledR}$

\section{INTRODUCTION}

Antibiotic growth promoters (AGP) have been used as a feed additive in poultry industry to enhance gut health and to control sub-clinical diseases. With increasing public concerns about bacterial resistance to antibiotics, the use of antibiotics in therapeutic or subtherapeutic doses in poultry feed has been severely limited or eliminated in many countries. European Union has preventively banned the use of antibiotics as growth promoters since $1^{\text {st }}$ January 2006 (Catala-Gregori et al., 2008). Therefore, alternatives to AGP need to be proposed to livestock producers in order to maintain animal health, productivity and carcass quality.

Department of Animal Science, Faculty of Agriculture, University of Peradeniya, Sri Lanka

Author for correspondence: alshiromi@yahoo.co.uk 
Moringa is the sole genus in the flowering plant family Moringaceae. This genus comprises 13 species, all of which are trees that grow in tropical and sub-tropical climates. Every part of the Moringa oleifera tree, from the roots to the leaves has beneficial properties. It is a multipurpose tree, various parts of which are used as fodder, herbal medicine, spices, food, natural coagulants, nectar for bees, fuel and fertilizer. Moringa contains very high antioxidants and anti-inflammatory compounds (Yang, et al., 2006). The leaves, flowers and pods are used as good sources of vitamins A, B and C, riboflavin, nicotinic acid, folic acid, pyridoxine, ascorbic acid, beta-carotene, calcium, iron, and alpha-tocopherol (Dahot, 1988). The pods are considered as an important source of the essential amino acids. A compound, pterygospermin found in the flowers and roots of the Moringa has powerful antibiotic and fungicidal effects (Das et al., 1957). The root bark contains two alkaloids: moringine and moringinine. Moringinine acts as cardiac stimulant, increases blood-pressure, acts on sympathetic nerve-endings as well as smooth muscles all over the body, and depresses the sympathetic motor fibers of vessels in large doses only. Aqueous leaf extracts are being used to treat hyperthyroidism as they help regulating thyroid hormone (Tahiliani \& Kar, 2000). Leaf extracts are also used to treat ulcer (Pal et al., 1995). It has been reported that Moringa leaves and pods also have a positive effect in reducing blood cholesterol (Ghasi et al., 2000), and anti-tumor promoting activity (Guevara et al., 1999). Nevertheless, it is an important source of the glucosinolate precursors of the isothiocyanate group of chemopreventives (Daxenbichler et al., 1991) that can inhibit carcinogenesis. Moringa is a potential plant that could be used to enhance immune responses and to improve intestinal health of broiler chicken. Yang, et al. (2006), reported that the dehydrated leaves of M. oleifera in the diets of broiler chicken significantly enhanced immune responses and reduced E. coli and increased Lactobacillus counts in ileum. Hence, Moringa has a great potential in improving nutrition and strengthening immune functions of broiler chicken.

Zigbir $^{\circledR}$ is a commercially available feed additive which is a synergistic blend of phytochemical actives with performance enhancing characteristics. The four herbal plant parts Andrographis paniculata, Solanum nigrum, Phylanthus niruni and Boerhavia diffusa are used in the preparation of Zigbir ${ }^{\circledR}$. It has been shown that these herbs have beneficial effect on liver health and productivity of animals (Kapil et al., 1993). Therefore, objective of the present study was to evaluate the beneficial effects of selected herbal feed additives on the growth performance and carcass quality of broiler chicken. It was hypothesized in this study that the selected herbal feed additives would improve the growth performance and carcass quality of broiler chicken without any negative consequence for health and performance of broiler chicken.

\section{MATERIALS AND METHODS}

\section{Experimental design and animals}

Three hundred and eight day-old male broiler chicks of Indian River strain were purchased from the Ceylon Grain Elevators PLC (Prima Group) and assigned into seven dietary treatments in a complete randomized design. After two weeks of brooding period in the electrically heated battery brooder, each group was divided into four equal replicates to have eleven chicks per replicate. The chicks were housed in floor pens $\left(1 \mathrm{ft}^{2} / \mathrm{bird}\right)$ after brooding. The brooder temperature was maintained at $32{ }^{\circ} \mathrm{C}$ during the first week using electric bulbs and gradually decreased thereafter by switched off the lights during day times while 
considering the behaviour pattern of the chicks. The relative humidity of the brooder and floor pens during the experiment was $70 \%$.

\section{Experimental diet and dietary treatments}

Corn-soya based broiler starter and finisher basal diets were formulated according to the ingredient composition given in Table 1. Moringa leaf powder and Moringa fruit powder were prepared in the laboratory. Moringa fruit was peeled, washed, cut into small pieces and kept in the oven at $60{ }^{\circ} \mathrm{C}$ for about six hours. After oven drying, they were ground and sieved to obtain powder form. Moringa leaves were kept in the oven at $60{ }^{\circ} \mathrm{C}$ for about six hours, ground and sieved. Seven dietary treatments namely $0.05 \%$ and $0.1 \%$ Moringa fruit powders, $0.05 \%$ and $0.1 \%$ Moringa leaf powders, $0.035 \%$ commercial herbal preparation Zigbir ${ }^{\circledR}$, $0.0125 \%$ flavomycin (positive control) and the negative control were prepared. Starter diets and finisher diets were offered adlibitum from day 1 to 21 and from day 22 to 42 , respectively. Clean water was provided all the time. The birds were vaccinated twice against Gumboro (Infectious Bursal Disease) on day 12 and day 21.

\section{Body weights and feed intake}

The average group body weights and feed consumption were recorded at weekly intervals $\left(7^{\text {th }}, 14^{\text {th }}, 21^{\text {st }}, 28^{\text {th }}, 35^{\text {th }}\right.$ and $42^{\text {nd }}$ days) during the experimental period. Body weight gains and feed conversion ratio (FCR) were calculated using the above measurements.

\section{Carcass characteristics}

The birds were slaughtered at $42^{\text {nd }}$ day after withdrawal of feed 12 hours before slaughtering. The live body weights (LBW) of birds were recorded. The birds were slaughtered by cutting the jugular vein and after complete bleeding, the weights were recorded. The birds were then defeathered and eviscerated. Respective bird's weights and the weights of eviscerated gut and organ were measured. Finally, the dressed weights of birds were measured after removing head and shank. At the end of slaughtering process, the carcass quality parameters such as abdominal fat content (fat around gizzard, vent and heart), subcutaneous fat content (clavico-cervical (neck), pectoral-lateral thoracic (breast), sartorial femoral (leg)) were measured using five samples from each replicate (twenty birds per treatment). Illustrations of the main subcutaneous fat depots are shown in Fig. 1.

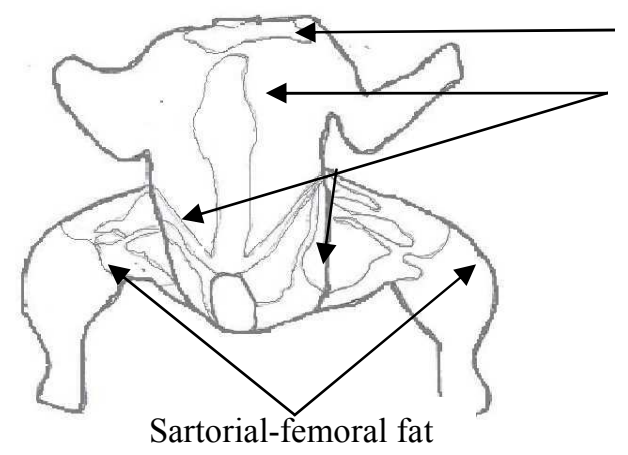

Clavico-cervical fat

Pectoral-lateral thoracic fat

Fig. 1. Main subcutaneous fat depots 
Table 1. Ingredient composition and estimated nutrient composition of broiler starter and finisher basal diets

\begin{tabular}{|c|c|c|}
\hline Ingredient & $\begin{array}{l}\text { Broiler } \\
\text { Starter \% }\end{array}$ & $\begin{array}{l}\text { Broiler } \\
\text { Finisher \% }\end{array}$ \\
\hline Maize & 49.00 & 40.00 \\
\hline Rice polish & 08.00 & 21.00 \\
\hline Fish meal & 04.80 & 0.00 \\
\hline Soybean meal & 27.70 & 21.00 \\
\hline Coconut poonac & 5.00 & 10.00 \\
\hline Shell grit powder & 2.08 & 2.70 \\
\hline DCP & 0.50 & 0.40 \\
\hline L-Lysine & 0.10 & 0.50 \\
\hline D.L. Methionine & 0.20 & 0.40 \\
\hline Coconut oil & 2.00 & 3.40 \\
\hline Salt & 0.30 & 0.30 \\
\hline Coccidiostat & 0.02 & 0.00 \\
\hline Broiler Premix & 0.30 & 0.30 \\
\hline Total & 100 & 100 \\
\hline \multicolumn{3}{|l|}{ Calculated nutrient composition } \\
\hline Metabolizable energy $(\mathrm{kcal} / \mathrm{kg})$ & 3100 & 3100 \\
\hline Crude protein $(\%)$ & 22.22 & 18.30 \\
\hline Calcium (\%) & 1.50 & 1.50 \\
\hline Phosphorus (\%) & 0.78 & 0.70 \\
\hline Lysine $(\%)$ & 1.16 & 0.96 \\
\hline Methionine (\%) & 0.53 & 0.52 \\
\hline Methionine + Cystine $(\%)$ & 0.93 & 0.89 \\
\hline \multicolumn{3}{|c|}{ Estimated composition, $\%$ of dry matter } \\
\hline Ether extract & 7.13 & 10.43 \\
\hline Crude fibre & 4.85 & 5.68 \\
\hline Ash & 8.87 & 9.25 \\
\hline Nitrogen free extract & 50.25 & 52.07 \\
\hline
\end{tabular}

\section{Statistical analysis}

The data were analyzed by ANOVA using SAS software package. The mean separation was done by using Duncan's multiple range test (Duncan, 1955).

\section{RESULTS AND DISCUSSION}

\section{Growth performance}

The effects of herbal feed additives on body weight gain, feed consumption and feed conversion ratio of broiler chicks during the starter (0-21 days) and finisher (22-42 days) for total (0-42 days)periods are presented in Table 2. There were significant differences recorded in the body weight gain and FCR during finisher and total periods. Significant differences in 
feed intake of chicks were observed only in the total period. The positive control diet and the diets supplemented with herbal feed additives significantly improved the body weight gain and FCR of broiler chicks during finisher and total periods compared to the negative control. This finding revealed that a growth promoter effect was exerted by the herbal feed additives similar to the antibiotic growth promoter. In addition, the herbal feed additives improved the FCR of broiler chicken similar to the antibiotic growth promoter. Several research findings reported that herbal extracts could increase the broiler performance by improving live weight gain and FCR of broiler chicken (Jamroz and Kamel, 2002; Jamroz et al., 2003; Al-Kassie and Jameel, 2009). In contrast, Botsoglou et al. (2002) showed that oregano oil showed no growth promoting effect when administered at 50 or $100 \mathrm{mg} / \mathrm{kg}$ of feed. The broiler chickens fed with diets containing the commercial herbal product, $\mathrm{Zigbir}^{\circledR}$ recorded the lowest FCR during total period and the highest body weight gain during finisher period even though it was not statistically different from the birds fed with Moringa based feed additives except $0.05 \%$ Moringa leaf powder level. This might be due to the digestion stimulatory and the gastroprotective effects as reported by Abdulla et al. (2010), for the herbal components Andrographis paniculata and Phylanthus niruri in the commercial herbal product Zigbir ${ }^{\circledR}$. Furthermore, the body weight gains of chicks were increased with the increasing percentages of both Moringa leaf and fruit powder during the finisher and total periods. Moreover, numerically lower FCR was recorded in the chicks when the percentage of Moringa leaf powder in the diet was increased. In contrast, the same was observed in the chicks when the percentage of Moringa fruit powder in the diet decreases. This could be due to the increase in feed intake when the percentage of Moringa fruit powder in the diet increases.

\section{Carcass quality}

Effects of herbal feed additives on the carcass characteristics of broiler chicken are presented in Table 3. The results of the present study indicated that all the herbal dietary treatments improved $(\mathrm{P}<0.05)$ the live weight and carcass yield significantly. The herbal dietary supplements increased $(\mathrm{P}<0.05)$ the live weight, weight after bleeding, weight after defeathering and dressing percentage of broiler chicken similar to the positive control diet. This might be due to the improvement in the digestibility of feed ingredient by the inclusion of herbal dietary supplements (Jamroz et al., 2003) and the growth promoting effect of antibiotics in positive control. The present findings supported the concept that plant extracts improved the carcass yield of broiler chicken as reported by Alcicek et al. (2004). Moreover, the findings revealed that live weight, weight after bleeding, weight after defeathering increased with increasing levels of Moringa leaf and fruit powders. Total organ weights were found to be lower in the birds fed with antibiotic as well as $0.05 \%$ Moringa fruit powder. This might be due to the gut thinning and shortening effect of antibiotics as reported by Visek (1978). A significant effect of herbal dietary treatment was not observed on subcutaneous fat content (neck, breast and leg) of broiler carcass and on abdominal fat content (heart and vent) except the fat around gizzard. This finding is similar to the observation made by Sarica et al. (2005), and Cabuk et al. (2006), that, oregano leaf extracts had no significant effect on the carcass characteristics of birds. The dietary herbal supplement of $0.1 \%$ of Moringa fruit powder increased the gizzard fat content while $0.1 \%$ of Moringa leaf powder reduced the same. This observation suggests that different parts of the plants have varying effects on the carcass characteristics of birds. 
Table 2. Effect of dietary supplemental herbal preparations on growth performance of broiler chicks from 0-42 day.

\begin{tabular}{|c|c|c|c|c|c|c|c|}
\hline \multirow{2}{*}{ Parameter $\pm \mathrm{SE}^{*}$} & \multicolumn{7}{|c|}{ Treatment** } \\
\hline & $\mathbf{N C}$ & $\mathbf{P C}$ & MLP 0.1\% & MLP 0.05\% & Zigbir $^{\circledR}$ & MFP 0.1\% & MFP $0.05 \%$ \\
\hline \multicolumn{8}{|c|}{ Body weight gain \pm SE (g) } \\
\hline $0-21$ days & $276 \pm 5.3^{\mathrm{ab*}}$ & $331 \pm 5.6^{\mathrm{a}}$ & $257 \pm 5.7^{\mathrm{b}}$ & $264 \pm 6.7^{b}$ & $269 \pm 6.4^{b}$ & $258 \pm 6.7^{\mathrm{b}}$ & $295 \pm 5.4^{\mathrm{ab}}$ \\
\hline $22-42$ days & $648 \pm 7.7^{\mathrm{c}}$ & $932 \pm 4.6^{\mathrm{ab}}$ & $874 \pm 5.1^{\mathrm{ab}}$ & $857 \pm 11.7^{\mathrm{b}}$ & $975 \pm 9.0^{\mathrm{a}}$ & $955 \pm 5.9^{\mathrm{ab}}$ & $895 \pm 7.9^{\mathrm{ab}}$ \\
\hline $0-42$ days & $923 \pm 9.1^{b}$ & $1262 \pm 3.2^{\mathrm{a}}$ & $1131 \pm 6.0^{\mathrm{a}}$ & $1122 \pm 13.5^{\mathrm{a}}$ & $1244 \pm 9.8^{\mathrm{a}}$ & $1213 \pm 6.9^{a}$ & $1190 \pm 9.6^{\mathrm{a}}$ \\
\hline \multicolumn{8}{|c|}{ Weekly Feed intake \pm SE (g/bird) } \\
\hline $0-21$ days & $676 \pm 0.0^{\mathrm{a}}$ & $775 \pm 0.0^{\mathrm{a}}$ & $641 \pm 0.0^{\mathrm{a}}$ & $763 \pm 0.0^{\mathrm{a}}$ & $652 \pm 0.0^{\mathrm{a}}$ & $774 \pm 0.0^{\mathrm{a}}$ & $742 \pm 0.0^{\mathrm{a}}$ \\
\hline $22-42$ days & $1901 \pm 12.6^{\mathrm{a}}$ & $2046 \pm 5.8^{\mathrm{a}}$ & $2052 \pm 8.9^{\mathrm{a}}$ & $1983 \pm 11.5^{\mathrm{a}}$ & $2052 \pm 9.8^{\mathrm{a}}$ & $2066 \pm 13.7^{\mathrm{a}}$ & $2001 \pm 11.7^{\mathrm{a}}$ \\
\hline $0-42$ days & $2577 \pm 12.6^{\mathrm{b}}$ & $2822 \pm 5.8^{\mathrm{a}}$ & $2694 \pm 8.9^{\mathrm{ab}}$ & $2747 \pm 11.5^{\mathrm{ab}}$ & $2704 \pm 9.8^{\mathrm{ab}}$ & $2841 \pm 13.7^{\mathrm{a}}$ & $2744 \pm 11.7^{\mathrm{ab}}$ \\
\hline \multicolumn{8}{|l|}{$\mathbf{F C R} \pm \mathbf{S E}$} \\
\hline $0-21$ days & $2.47 \pm 0.6^{\mathrm{ab}}$ & $2.36 \pm 0.5^{\mathrm{b}}$ & $2.53 \pm 0.6^{\mathrm{ab}}$ & $2.96 \pm 0.8^{\mathrm{ab}}$ & $2.47 \pm 0.7^{\mathrm{ab}}$ & $3.07 \pm 0.8^{\mathrm{a}}$ & $2.53 \pm 0.5^{\mathrm{ab}}$ \\
\hline $22-42$ days & $2.95 \pm 0.6^{\mathrm{a}}$ & $2.04 \pm 0.6^{\mathrm{b}}$ & $2.35 \pm 0.3^{\mathrm{b}}$ & $2.19 \pm 0.6^{\mathrm{b}}$ & $2.11 \pm 0.3^{\mathrm{b}}$ & $2.03 \pm 0.5^{\mathrm{b}}$ & $2.09 \pm 0.6^{\mathrm{b}}$ \\
\hline $0-42$ days & $2.80 \pm 0.5^{\mathrm{a}}$ & $2.24 \pm 0.2^{\mathrm{bc}}$ & $2.38 \pm 0.3^{\mathrm{bc}}$ & $2.49 \pm 0.6^{\mathrm{b}}$ & $2.18 \pm 0.3^{c}$ & $2.34 \pm 0.4^{\mathrm{bc}}$ & $2.31 \pm 0.4^{\mathrm{bc}}$ \\
\hline
\end{tabular}

* Means within the same raw having different letters are significantly different $(\mathrm{P}<0.05)$.

** Negative control (NC), $0.01 \%$ of flavomycine as positive control (PC), $0.1 \%$ of Moringa leaf powder (MLP $0.1 \%$ ), $0.05 \%$ of Moringa leaf powder (MLP $0.05 \%$ ), $0.035 \%$ Zigbir , $0.1 \%$ of Moringa fruit powder (MFP $0.1 \%$ ) and $0.05 \%$ of Moringa fruit powder (MFP $0.05 \%$ ). 
David et al.

Table 3. Effect of dietary supplemental herbal preparations on the carcass characteristics of broiler chicken.

\begin{tabular}{|c|c|c|c|c|c|c|c|}
\hline \multirow{2}{*}{ Parameter $\pm \mathrm{SE}^{*}$} & \multicolumn{7}{|c|}{ Treatment** } \\
\hline & NC & $\mathbf{P C}$ & MLP 0.1\% & MLP $0.05 \%$ & Zigbir $^{\circledR}$ & MFP $0.1 \%$ & MFP $0.05 \%$ \\
\hline Live Weight (g) & $1045 \pm 14.77^{\mathrm{c}^{*}}$ & $1304 \pm 10.78^{\mathrm{ab}}$ & $1220 \pm 13.20^{\mathrm{ab}}$ & $1212 \pm 13.94^{\mathrm{b}}$ & $1346 \pm 12.66^{\mathrm{a}}$ & $1271 \pm 15.06^{\mathrm{ab}}$ & $1251 \pm 12.50^{\mathrm{ab}}$ \\
\hline Dressing $\%$ & $69.68 \pm 1.8^{\mathrm{b}}$ & $71.75 \pm 1.2^{\mathrm{a}}$ & $71.29 \pm 1.3^{\mathrm{a}}$ & $71.08 \pm 1.3^{\mathrm{a}}$ & $71.60 \pm 1.3^{\mathrm{a}}$ & $71.02 \pm 1.3^{\mathrm{a}}$ & $71.76 \pm 1.2^{\mathrm{a}}$ \\
\hline Weight after bleeding (g) & $1012 \pm 14.6^{\mathrm{c}}$ & $1268 \pm 10.5^{\mathrm{ab}}$ & $1180 \pm 12.8^{\mathrm{ab}}$ & $1171 \pm 13.7^{\mathrm{b}}$ & $1299 \pm 12.4^{\mathrm{a}}$ & $1232 \pm 14.7^{\mathrm{ab}}$ & $1216 \pm 12.4^{\mathrm{ab}}$ \\
\hline Weight after defeathering (g) & $972 \pm 14.4^{\mathrm{c}}$ & $1231 \pm 10.8^{\mathrm{ab}}$ & $1129 \pm 12.6^{\mathrm{b}}$ & $1128 \pm 13.4^{\mathrm{b}}$ & $1252 \pm 12.5^{\mathrm{a}}$ & $1187 \pm 14.5^{\mathrm{ab}}$ & $1163 \pm 12.1^{\mathrm{ab}}$ \\
\hline Total organ weight (\% LBW) & $14.60 \pm 1.30^{\mathrm{a}}$ & $13.07 \pm 1.04^{\mathrm{c}}$ & $13.25 \pm 1.12^{\mathrm{bc}}$ & $14.14 \pm 1.14^{\mathrm{ab}}$ & $13.26 \pm 1.12^{\mathrm{bc}}$ & $14.30 \pm 1.37^{\mathrm{a}}$ & $13.09 \pm 0.88^{\mathrm{c}}$ \\
\hline \multicolumn{8}{|c|}{ Abdominal fat (\% carcass weight) } \\
\hline Gizzard & $0.73 \pm 0.64^{\mathrm{ab}^{*}}$ & $0.81 \pm 0.52^{\mathrm{ab}}$ & $0.65 \pm 0.53^{\mathrm{b}}$ & $0.79 \pm 0.55^{\mathrm{ab}}$ & $0.81 \pm 0.60^{\mathrm{ab}}$ & $0.91 \pm 0.61^{\mathrm{a}}$ & $0.69 \pm 0.44^{\mathrm{ab}}$ \\
\hline Heart & $0.11 \pm 0.30^{\mathrm{a}}$ & $0.12 \pm 0.27^{\mathrm{a}}$ & $0.09 \pm 0.20^{\mathrm{a}}$ & $0.08 \pm 0.21^{\mathrm{a}}$ & $0.12 \pm 0.25^{\mathrm{a}}$ & $0.09 \pm 0.18^{\mathrm{a}}$ & $0.11 \pm 0.20^{\mathrm{a}}$ \\
\hline Vent & $1.52 \pm 0.84^{\mathrm{a}}$ & $1.71 \pm 0.73^{\mathrm{a}}$ & $1.52 \pm 0.78^{\mathrm{a}}$ & $1.74 \pm 0.81^{\mathrm{a}}$ & $1.75 \pm 0.87^{\mathrm{a}}$ & $1.67 \pm 0.78^{\mathrm{a}}$ & $1.89 \pm 0.87^{\mathrm{a}}$ \\
\hline \multicolumn{8}{|c|}{ Subcutaneous fat (\% carcass weight) } \\
\hline Neck & $0.92 \pm 0.65^{\mathrm{a}}$ & $0.99 \pm 0.55^{\mathrm{a}}$ & $0.86 \pm 0.54^{\mathrm{a}}$ & $1.05 \pm 0.61^{\mathrm{a}}$ & $1.03 \pm 0.69^{\mathrm{a}}$ & $1.03 \pm 0.71^{\mathrm{a}}$ & $1.08 \pm 0.48^{\mathrm{a}}$ \\
\hline Breast & $0.30 \pm 0.37^{\mathrm{a}}$ & $0.21 \pm 0.25^{\mathrm{a}}$ & $0.28 \pm 0.39^{\mathrm{a}}$ & $0.25 \pm 0.28^{\mathrm{a}}$ & $0.28 \pm 0.39^{\mathrm{a}}$ & $0.23 \pm 0.28^{\mathrm{a}}$ & $0.28 \pm 0.32^{\mathrm{a}}$ \\
\hline Leg & $0.76 \pm 0.56^{\mathrm{a}}$ & $0.69 \pm 0.41^{\mathrm{a}}$ & $0.67 \pm 0.54^{\mathrm{a}}$ & $0.83 \pm 0.51^{\mathrm{a}}$ & $0.75 \pm 0.52^{\mathrm{a}}$ & $0.87 \pm 0.53^{\mathrm{a}}$ & $0.75 \pm 0.49^{\mathrm{a}}$ \\
\hline
\end{tabular}

* Means within the same row having different letters are significantly different $(\mathrm{P}<0.05)$.

** Negative control (NC), $0.01 \%$ of flavomycine as positive control (PC), $0.1 \%$ of Moringa leaf powder (MLP $0.1 \%$ ), $0.05 \%$ of Moringa leaf powder (MLP $0.05 \%$ ), $0.035 \%$ Zigbir ${ }^{\circledR}$

$0.1 \%$ of Moringa fruit powder (MFP $0.1 \%$ ) and $0.05 \%$ of Moringa fruit powder (MFP $0.05 \%$ ). 


\section{CONCLUSIONS}

The study concludes that selected herbal dietary supplements Moringa leaf powder, Moringa fruit powder and the commercial herbal product $\mathrm{Zigbir}^{\circledR}$ have the potential to improve the growth performance and carcass yield of broiler chicken.

\section{ACKNOWLEDGEMENT}

Financial support by Council for Agricultural Research Policy and Agrinova Pvt. (Ltd.) to this experiment is gratefully acknowledged.

\section{REFERENCES}

Abdulla, M., A., Ahmed, K.A., AL-Bayaty, F.H. and Masood, Y. (2010). Gastroprotective effect of Phyllanthus niruri leaf extract against ethanol-induced gastric mucosal injury in rats. Afr. J. Pharm. Pharacol. 4, 226-230.

Alcicek, A., Bozkurt, M. and Cabuk, M. (2004). The effect of a mixture of herbal essential oils, an organic acid or a probiotic on broiler performance. S. Afr. J. Anim. Sci. 34, 217-222.

Al-Kassie, G.A.M. and Jameel, Y.J. (2009). The effect of adding Thyme vulgaris and cinnamomuim zeylanicum on productive performance in broilers. Proceeding of 9th Veterinary Scientific Conference, College Veterinary Medicine, University of Baghdad, Iraq.

Botsoglou, N.A., Florou-Paneri, P., Christaki, E., Fletouris, D.J. and Spais, A.B. (2002). Effect of dietary oregano essential oil on performance of chickens and on iron-induced lipid oxidation of breast, thigh and abdominal fat tissues. Br. Poult. Sci. 43, 223-230.

Cabuk, M., Bozkurt, M. Alcicek, A., Cath A.U. and Baser, K.H.C. (2006). Effect of a dietary essential oil mixture on performance of laying hens in the summer season. S. Afr. J. Anim. Sci. 36, 215-221.

Catalá-Gregori, P., Mallet, S., Travel, A. and Lessire, M. (2008). Efficiency of a prebiotic and a plant extract on broiler performance and intestinal physiology. 16th European Symposium on Poultry Nutrition, World Poultry Science Association, Strasbourg, France.

Dahot, M.U. (1988). Vitamin contents of the flowers of Moringa oleifera. Pakistan J. Biochemistry. 21, 1-2, 21-24.

Das, B.R., Kurup, P.A. and Rao, P.L.N. (1957). Antibiotic principle from Moringa pterygosperma: VII. Antibacterial activity and chemical structure of compounds related to pterygospermin. India J. Med. Res., 45,191-196.

Daxenbichler, M.E., Spencer, G.F., Calson, D.G., Rose, G.B., Brinker, A. M and Powell, R.G. (1991). Glucosinolate composition of seeds from 297 species of wild plants. Phytochemistry, 30, 2623-2638.

Duncan, D.B. (1955). Multiple range and multiple F tests. Biometrics, 11, 1-42. 
Ghasi, S., Wobodo, E.N., and Ofili, J.O. (2000). Hypocholesterolemic effects of crude extract of leaf of Moringa oleifera Lam in high-fat diet fed Wistar rats. J. Ethnopharmacol. 69(1), 21-25.

Guevara, A.P., Vargas, C., Sakurai, H., Fujiwara, Y., Hashimoto, K., Maoka, T., Kozuka, M., Ito, Y., Tokuda, H. and Nishino, H. (1999). An antitumor promoter from Moringa oleifera Lam. Mutat. Res. 440, 181-188.

Jamroz, D. and Kamel, C. (2002). Plant extracts enhance broiler performance. J. Anim. Sci. 80 (Suppl.1):4. (Abstr.).

Jamroz, D., Orda, J., Kamel, C., Wiliczkiewicz, A., Wertelecki, T. and Skorupinska, J. (2003). The influence of phytogenic extracts on performance, nutrient digestibility, carcass characteristics and gut microbial status in broiler chickens. J. Anim. Feed Sci. 12, 583-596.

Kapil, A., Koul, I.B., Banerjee, S.K., Gupta, B.D., (1993). Antihepatotoxic effects of major diterpenoids constituents of Andrographis paniculata. Bichem. Pharmacol. 46, 182-185.

Pal, S.K., Mukherjee, P.K. and Saha, B.P, (1995). Studies on the antiulcer activity of Moringa oleifera leaf extract on gastric ulcer models in rats. Phytother. Res. 9, 463-465.

Sarica, S., Ciftci, A., Demir, E., Kilinc, K. and Yildirim, Y. (2005). Use of an antibiotic growth promoter and two herbal natural feed additives with and without exogenous enzymes in wheat based broiler diets. S. Afr. J. Anim. Sci. 35, 61-72.

Tahiliani, P. and Kar, A. (2000). Role of Moringa oleifera leaf extract in the regulation of thyroid hormone status in adult male and female rats. Pharmacol. Res. 41(3), 319-323.

Visek, W.J. (1978). The mode of growth promotion by antibiotics. J. Anim. Sci. 46, 14471469.

Yang, R., Chang, L.C., Hsu, J.C., Weng, B.B.C., Palada, M.C., Chadha, M.L. and Levasseur, V. (2006). Nutritional and functional properties of Moringa leaves -from Germplasm, to plant, to food, to health. Moringa and other highly nutritious plant resources: Strategies, standards and markets for a better impact on nutrition in Africa. Accra, Ghana. www.treesforlifejournal.org. Accessed 25 ${ }^{\text {th }}$ May, 2012. 